\title{
Employee Job Satisfaction and Work Motivation in The Context of Public Sector Organization.
}

\author{
${ }^{1}$ Aldona A Somava \\ ${ }^{1}$ Engineering Management Division, Poznań University of Technology, 60-965 Poznań, Poland \\ 1asomaya893@hotmail.com
}

\author{
Article Info \\ Journal of Journal of Enterprise and Business Intelligence (http://anapub.co.ke/journals/jebi/jebi.html) \\ Doi: https://doi.org/10.53759/5181/JEBI202101012 \\ Received 30 September 2020; Revised form 30 October 2020; Accepted 29 December 2020. \\ Available online 05 April 2021. \\ (C)2021 Published by AnaPub Publications.
}

\begin{abstract}
The purpose of this research was to measure the effect of work motivation on employee job satisfaction in Ceylon Electricity Board (CEB), Batticaloa district. A Self-administered questionnaire consisting of several measures was employed to gather data from the technical and supporting employees who work in different sections of the CEB like the Distribution Maintenance Office, Area Chief Engineer Office, Distribution Construction Engineer Office and Sub Stores of Batticaloa district. A simple random sampling method was applied to get 285 responses from the respondents. The gathered data were utilized to test the model using the PLS-SEM approach with Smart PLS. The results showed that the essential features of work motivation are manager's leadership styles, motivation practices, employee job expectations, reward management system and working environment, whereas the identified consequence was employee job satisfaction. All five variables had a positive effect on job satisfaction and among them, employee job expectations and manager's leadership style had the highest influence and the reward management system had the least influence on job satisfaction. Further, this study offers thoughts for managers by pinpointing the critical factors influencing that motivate employees in CEB.
\end{abstract}

Keywords - Motivation, Reward system, Job satisfaction, Public sector, Structural equation modelling

\section{INTRODUCTION}

Living in the 21 st century and adapting to society being in a steady development, makes managers wonder how to hold their most important workers. Terms like motivation and job satisfaction are being looked nearer upon, and a large number of the present best managers are truly keen on what their workers are thinking. Managers also accept that firms can't run and accomplish their longing objectives and destinations without propelling their worker [1]. The workers who are inspired have a sense of belonging, recognition with achievement and effort to perform commendably well in their functions [2]. Incited workers can help make an organization seriously more worth added and beneficial [3]. On the other hand, if the motivation is not designed well, it makes an incompetent and non-willing job performer [4].

Job satisfaction is viewed as delicate or enthusiastic reaction towards different realities of one's activity. It drives that job satisfaction is definitely not a unitary idea; rather, an individual can be generally happy with single perspective. Job satisfaction of workers is associated with motivation and effects workers to ensure maximum utilization of their efforts to reach organizational objectives [5]. Job satisfaction is a worker's sense of accomplishment and success in the job. Many workers measure their job satisfaction only in terms of the outcomes of their efforts [6].

In the Sri Lankan context, organizations are primarily split into two divisions, the public and private sectors. The public sector is classified into various categories such as statutory boards, authorities, corporations, departments, etc. Further, it is perceived that job satisfaction of employees in the public sector is comparatively greater than that in the private sector. Against this general tendency, it is now noted that the current level of job satisfaction is quite low among non-executive employees in CEB. As shown by [7], employee satisfaction is lowering due to the increase in work life conflict among CEB non-executive employees. CEB afraid that this lowering level of job satisfaction among employees has prompted them to bring several workable measures but nothing worked better [8]. Therefore, the motivational practices undertaken by CEB (Batticaloa district) need revision to work well to increase job satisfaction. In this way, the factors affecting employee job satisfaction can be dependent on many factors. A framework for enhancing employee satisfaction proposed by [9] consists of five factors such as manager's leadership style, motivation practices, reward management system, employee job expectations and working environment, provide many insights to understanding the motivation practices of any given organization. The significance of employee job satisfaction and work motivation is growing all the time in the organization [10]. There are numerous examinations have investigated the current pattern on a worldwide scale however not in a localized context [11]. 
Based on this research gap, the present study was designed to explore how manager's leadership style, motivation practices, reward management system, employee job expectations and working environment enhance job satisfaction in CEB in Batticaloa district. This study attempts to address the following question:

RQ. What are the effects of manager's leadership style, motivation practices, reward management system, employee job expectations and working environment on employee job satisfaction?

Therefore, the aim of this study is to assess the influence of employee motivation on job satisfaction in CEB in Batticaloa district. Further, this study would facilitate for additional research and examination of different ideas in this arena. It will also offer insight into the fact that how job satisfaction can be enhanced within establishments. Moreover, this study contributes to the empirical knowledge by giving evidence of the impact of motivation on employee job satisfaction in Sri Lankan public sector organizations, especially in CEB. This research will enable us to use as a spectrum for all public sector organizations in Sri Lanka in determining the effect of work motivation on employee job satisfaction and to make HRM- related decisions to drive the organization towards its success.

The study is structured as follows: First, it examines the theoretical basis as well as the research hypotheses then, outlines the methodology used, presents the results and then provides a discussion. Finally, it offers conclusions and limitations of the study.

\section{THEORETICAL BASIS AND RESEARCH HYPOTHESIS}

\section{Relationship between Work Motivation and Job Satisfaction}

The concept of motivation is often linked to job satisfaction [12]. The relationship between work motivation and job satisfaction has been supported by several studies in different areas. Employees have to spend most of their time at workplace and need satisfaction at that place. Supporting this outlook, Springer (2011) investigates the link between work motivation and job satisfaction and concludes that work motivation increases, and job satisfaction also tends to increase . Similarly, profuse researchers have agreed on their findings that job satisfaction is very much rely on work motivation. [13] showed that work motivation influences job satisfaction of university academics. Above all, job satisfaction would be reached when an employee is motivated to do work by his/her own will [14]. The proposed model for this study shows a connection between motivation and job satisfaction, as suggested by [15], who pinpoints that specific factors like manager's leadership style, motivation practices, reward management system, employee job expectations and working environment are commonly identified influences upon employee satisfaction. The figure 1 shows the research model.

The relationship of job satisfaction with mangers' leadership style, motivation practices, reward management system, employee job expectations and working environment are explained below:

\section{Relationship between Manager's Leadership Style and Job Satisfaction}

Manager's leadership style in motivation has been regarded as one of the influential factors in employee job satisfaction. A study by [16] displayed that manager's leadership style in motivation can provide the job satisfaction to employees. Similarly, [17] exhibited that the leadership style of managers contributes to employee's job satisfaction in five-star hotels. In this way, [18] conducted an analysis on the link between leadership style and job satisfaction of library staff was revealed a positive relationship, which means the better the leadership style found in an entity, the higher the level of job satisfaction felt by employees. Therefore, the following hypothesis is formulated:

H1: Better the leadership style the higher the level of job satisfaction

\section{Relationship between motivation practices and Job Satisfaction}

Motivation and job satisfaction are indispensable components for holding employees and in fact the motivation is a higher priority than job satisfaction [19]. As indicated by [20], motivation is at all is essential to drive workers to perform by filling to their desires. A few investigations were conducted about the relationship of motivation and job satisfaction. [21] indicated a positive relationship between motivation and job satisfaction among a group of information specialists. Similarly, [22] demonstrated that motivation has a significant positive relationship with job satisfaction. In the educational institutions, research uncovered that there is positive link between motivation and job satisfaction of instructors [23]. Along these lines, the examination estimated that: 
H2: Higher level of motivation leads to higher level of job satisfaction

Relationship between hypothesis between reward management system and Job Satisfaction

It is well acclaimed that both financial and non-financial rewards are influencing the motivation and job satisfaction of employees. Thus, organizations should opt proper reward systems to increase employees' job satisfaction. [25] recommend that the kind of reward system in which employees perform strongly impact the satisfaction. Many studies have shown positive results about the links between reward system and employee's job satisfaction [24]. Further, a study conducted by [26] found a positive relationship between rewards system and job satisfaction. Comparable outcomes were found in research done by [27], that employee's job satisfaction is positively predisposed by reward. As indicated by [28], for non-managers, job satisfaction is influenced by more extrinsic rewards than intrinsic rewards. Thus, the following hypothesis is formulated.

H3: Better the reward management system higher the level of job satisfaction

\section{Relationship between employee job expectations and Job Satisfaction}

Expectations part contains the inquiries regarding how the workers feels about the fate of his/her work and his/her Expectations concerning it. The organization should structure the jobs with the goal that they will meet the worker's desires. Job satisfaction and disappointment not just relies upon the nature of the work, it also relies upon the expectations what the work supply to a worker [29] On the other hand, that the job disregards to meet such desires, employees will in general be disappointed. Baffled workers assume a notable role in work dissatisfaction. One of the components of the worker expectation is the job security at the work place, implying that the likelihood to lose the employment is very low. At the point when the job expectations are accomplished, workers will in general be satisfied. Moreover, [30] disclosed a positive relationship between work expectations and job satisfaction. Hence, it is hypothesized as under:

H4: Meeting employee job expectations leads to employee satisfaction

\section{Relationship between Working environment and satisfaction}

The working outcomes are straightforwardly interlinked with workplace. The more relaxed the workplace is helpful to increase the productivity of the workers, further the worker will favor to work in a domain which is conducive for them [31]._The board must ensure that workplace is protected and working can be adaptable. Also, Job satisfaction is a form of worker reaction to workplace conditions [32]. Similarly, [33] displayed that satisfaction with working environment is positively connected with work achievement. Hence, the hypothesis is formulated as below:

H5: The better the environment is higher the level of the satisfaction

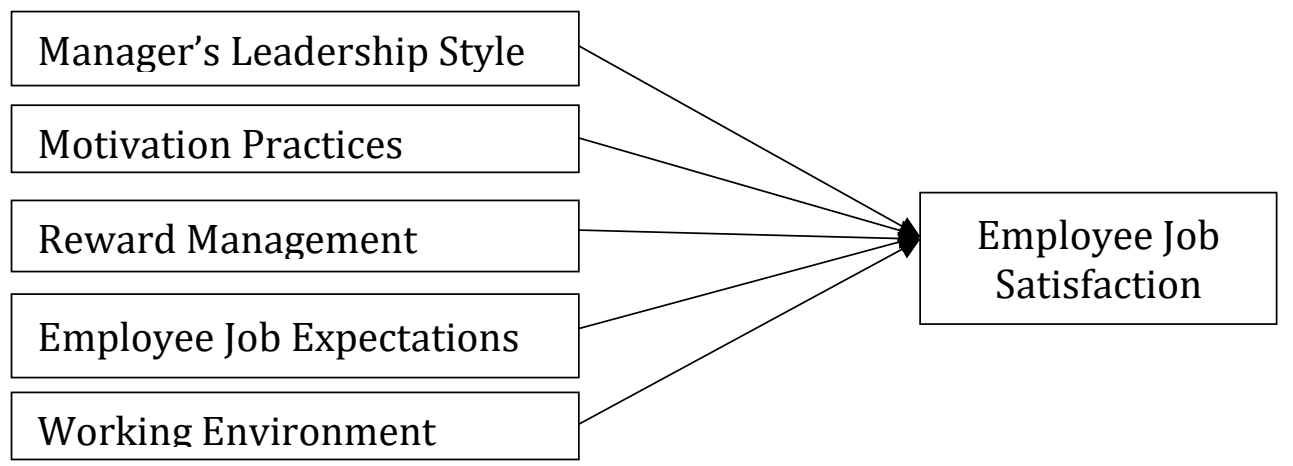

Fig 1: Research model

\section{RESEARCH METHODOLOGY}

This section describes the research framework, population, selection of the sample, and the process of the survey instrument.

\section{Research framework}

This research attempts to analyze the effect of work motivation on employee satisfaction in CEB, Sri Lanka by using a quantitative approach. Manager's leadership style, motivation practices, reward management system, employee job expectations and working environment provide, are taken as independent variable, while employee's satisfaction is 
taken as dependent variable. A self-administered questionnaire was used collect the data. Further, data were analyzed by applying PLS-SEM analysis using Smart PLS.

\section{Population and Sampling}

The population of interest was the cohort of technical and supporting service category of employees which comprise middle level technical service, skilled technical service, clerical and allied service, driver service and office employee service at Ceylon Electricity Board in Batticaloa District which consisted of Three hundred ninety five employees (395)

Sample size was calculated using sample size calculator. 99\% confidence level was chosen as the researcher wanted to ensure highest accuracy in the results. At 5\% confidence interval, the sample needed was 248 . However, $15 \%$ nonresponse rate was expected and hence 285 (248 x 1.15) sample-size was decided for this study. Thus, 285 (Technical service 132+ Supporting service 153) samples were selected using simple random sampling method, as the population framework for the target population is known for this study.

The study engaged 285 employees from technical and supportive service unit of CEB, Batticaloa District. Most of the respondents were male, $97.5 \%$, female $2.5 \%$. The vast majority of the workers are aged between 31-40 years with $39.6 \%$. The detailed table 1 below illustrated, the information about respondents.

\section{Survey instrument}

The survey for this study was carried out using a self-administered questionnaire comprising 37 items. Leadership style (07) items, Motivation practices (07) items, Reward system (04), Employee expectations (05), Working environment (04), and Job satisfaction (10). The items on the questionnaire were responded to using a 5-point Likert scale ranging from (1) Strongly disagree, through (2) Disagree, (3) Neutral, (4) Agree, and ending in (5) Strongly Agree.

Table 1: Demographic Profile of the Sample

\begin{tabular}{cccc}
\hline \multirow{2}{*}{ Gender } & Category & $\mathbf{N}$ & \% \\
& Male & 278 & 97.5 \\
\multirow{3}{*}{ Service Type } & Female & 7 & 2.5 \\
& & 132 & 46.3 \\
& Technical Service & 153 & 53.7 \\
Age & Supporting Service & 50 & 17.5 \\
& 21-30 years & 113 & 39.6 \\
& 31-40 years & 75 & 26.3 \\
Education Level & 41-50 years & 47 & 16.5 \\
& Above 50 years & 8 & 2.8 \\
& Less than ordinary level & 91 & 31.9 \\
& & 176 & 61.8 \\
& Ordinary level & 10 & 3.5 \\
\hline
\end{tabular}

\section{RESULTS AND FINDINGS}

This study opted the partial least squares structural equation modelling (PLS-SEM) method of data analysis employing Smart PLS3.2.7 (34). Smart PLS is right now the most complete programming for directing PLS-SEM examinations (35), the reason for using Partial Least Square analysis (PLS) in this study is to confirm previous theories about the effect of work motivation and job satisfaction of employee. PLS-SEM is a broadly recognized multivariate analytical method applied to estimate path models with latent variables (Rigdon 2016). The appraisal of PLS-SEM results includes a twostep approach: (1) the assessment of the measurement models; and (2) the evaluation of the structural model (36).

\section{Evaluation of Measurement model.}

The measurement model was evaluated by testing internal consistency reliability, convergent validity (CV) and discriminant validity (DV) (37). The score of the factor loading allows to assess individual item reliability. All factor loadings of reflective indicators were higher than 0.71 (38), except for the job satisfaction JS8 (0.554) item and Reward 
management R4 (0.649), which had a loading of less than 0.71 but more than 0.4. However, these items were retained as other items of the same construct have reached preferred AVE values (Avkiran 2018; Hair Jr et al. 2017b). Further, the lowest loading items such as Leadership style (03), L3, L4 and L6; Motivation practices (03), M2, M5, M6; Reward system (01), R3; Employee expectations (01), JE2; and Job satisfaction (06) , JS1, JS5, JS6, JS7, JS9, JS10 were dropped from the final analysis.

The reliability of the reflective constructs was measured by composite reliability (CR) and average variance extracted (AVE). Composite reliability (CR) was evaluated as a measure of internal consistency. As shown in Table 2, The results specified that the composite reliability for all of the constructs exceed the cut-off value (0.8). Motivation practices (0.919); manager's leadership style (0.906); employee job expectations (0.900); working environment (0.860); reward system( 0.827$)$ and job satisfaction (0.818) - thus showing the high internal consistency of the measures. Furthermore, all average variance extracted (AVE) scores exceed the threshold of 0.50 , indicating the construct measures' convergent validity. Table 2 shows the results of items loading, convergent validity (AVE) and composite reliability.

Lastly, Discriminant validity is checked through Fornell-Larker criterion; cross loading of the observed variables and the heterotrait-monotrait ratio of correlation (HTMT). Table 3 shows the square root of the AVE for all factors exceeded the cross correlation values, confirming the discriminant validity. Besides, the results of cross-loading scrutiny prove that each latent variable measures dissimilar items, see appendix 1. Moreover, HTMT approach used to decide the DV of the constructs. To attain DV the score of the HTMT should not to be above 0.90. In this research, all the scores are less than threshold values (0.90), confirming the uniqueness of all constructs, as shown in table 4. Further, the variance inflation factor (VIF) scores for all measures, ranging 1.34-4.55 which is less than (5), indicating no multicollinearity issue in the structural model. Table 3 shows the VIF value for the constructs.

Table 2: Results of items loading, convergent validity (AVE) and composite reliability

\begin{tabular}{|c|c|c|c|c|c|c|}
\hline Latent constructs & Items & Loadings & AVE & $\begin{array}{r}\text { Cronbach's } \\
\text { Alpha }\end{array}$ & $\mathbf{C R}$ & rho_A \\
\hline \multirow[t]{4}{*}{ Manager's Leadership style } & L1 & 0.910 & 0.71 & 0.865 & 0.906 & 0.906 \\
\hline & L2 & 0.917 & & & & \\
\hline & L5 & 0.803 & & & & \\
\hline & L7 & 0.725 & & & & \\
\hline \multirow[t]{4}{*}{ Motivation practices } & M1 & 0.907 & 0.743 & 0.885 & 0.919 & 0.944 \\
\hline & M3 & 0.677 & & & & \\
\hline & M4 & 0.918 & & & & \\
\hline & M7 & 0.922 & & & & \\
\hline \multirow[t]{3}{*}{ Reward system } & $\mathrm{R} 1$ & 0.825 & 0.602 & 0.673 & 0.818 & 0.71 \\
\hline & $\mathrm{R} 2$ & 0.840 & & & & \\
\hline & $\mathrm{R} 4$ & 0.649 & & & & \\
\hline \multirow[t]{5}{*}{ Employee expectations } & JE3 & 0.840 & 0.644 & 0.861 & 0.900 & 0.867 \\
\hline & JE1 & 0.827 & & & & \\
\hline & JE5 & 0.816 & & & & \\
\hline & JE4 & 0.775 & & & & \\
\hline & JE2 & 0.750 & & & & \\
\hline \multirow[t]{4}{*}{ Working environment } & WE1 & 0.747 & 0.608 & 0.791 & 0.860 & 0.816 \\
\hline & WE2 & 0.722 & & & & \\
\hline & WE3 & 0.921 & & & & \\
\hline & WE4 & 0.710 & & & & \\
\hline \multirow[t]{4}{*}{ Job satisfaction } & JS2 & 0.727 & 0.551 & 0.716 & 0.827 & 0.739 \\
\hline & JS3 & 0.869 & & & & \\
\hline & JS4 & 0.783 & & & & \\
\hline & JS8 & 0.554 & & & & \\
\hline
\end{tabular}


Table 3: Correlations and DV results

\begin{tabular}{|c|c|c|c|c|c|c|c|c|}
\hline & Mean & SD & $\begin{array}{l}\text { Employee } \\
\text { Job } \\
\text { Expectatio } \\
\text { ns }\end{array}$ & $\begin{array}{l}\text { Job } \\
\text { satisfact } \\
\text { ion }\end{array}$ & $\begin{array}{l}\text { Manager's } \\
\text { Leadershi } \\
\text { p Style }\end{array}$ & $\begin{array}{l}\text { Motivatio } \\
\mathrm{n} \\
\text { Practices }\end{array}$ & $\begin{array}{l}\text { Reward } \\
\text { Managem } \\
\text { ent } \\
\text { System }\end{array}$ & $\begin{array}{l}\text { Working } \\
\text { Environmen } \\
\mathrm{t}\end{array}$ \\
\hline $\begin{array}{l}\text { Employee } \\
\text { Job } \\
\text { Expectation } \\
\mathrm{s} \\
\end{array}$ & 2.673 & .965 & 0.802 & 1.518 & & & & \\
\hline $\begin{array}{l}\text { Job } \\
\text { satisfaction }\end{array}$ & 3.330 & 0.690 & 0.676 & 0.742 & 1.404 & 1.507 & 1.292 & 1.236 \\
\hline $\begin{array}{l}\text { Manager's } \\
\text { Leadership } \\
\text { Style }\end{array}$ & 2.84 & 0.931 & 0.42 & 0.57 & 0.842 & & & \\
\hline $\begin{array}{l}\text { Motivation } \\
\text { Practices }\end{array}$ & 3.380 & 0.724 & 0.435 & 0.521 & 0.419 & 0.862 & & \\
\hline $\begin{array}{l}\text { Reward } \\
\text { Managemen } \\
\text { t System }\end{array}$ & 3.053 & 0.696 & 0.313 & 0.363 & 0.268 & 0.043 & 0.776 & \\
\hline $\begin{array}{l}\text { Working } \\
\text { Environmen } \\
\mathrm{t}\end{array}$ & 3.164 & 0.713 & 0.342 & 0.499 & 0.255 & 0.287 & 0.283 & 0.78 \\
\hline
\end{tabular}

Note: Diagonal, italic elements represent square root of AVE, these should exceed the inter-construct correlations for adequate DV. Scores above diagonal elements are VIF Values.

Table 4: Heteroit - Monotrai Ratio (HTMT)

\begin{tabular}{|l|l|l|l|l|l|l|}
\hline & $\begin{array}{l}\text { Employee } \\
\text { Job } \\
\text { Expectation } \\
\mathrm{s}\end{array}$ & $\begin{array}{l}\text { Job } \\
\text { satisfactio } \\
\mathrm{n}\end{array}$ & $\begin{array}{l}\text { Manager's } \\
\text { Leadershi } \\
\text { p Style }\end{array}$ & $\begin{array}{l}\text { Motivatio } \\
\mathrm{n} \\
\text { Practices }\end{array}$ & $\begin{array}{l}\text { Reward } \\
\text { Managemen } \\
\text { t System }\end{array}$ & $\begin{array}{l}\text { Working } \\
\text { Environmen } \\
\mathrm{t}\end{array}$ \\
\hline Employee Job Expectations & & & & & & \\
\hline Job satisfaction & 0.850 & & & & & \\
\hline Manager's Leadership Style & 0.465 & 0.690 & & & & \\
\hline Motivation Practices & 0.461 & 0.636 & 0.451 & & & \\
\hline $\begin{array}{l}\text { Reward Management } \\
\text { System }\end{array}$ & 0.440 & 0.522 & 0.327 & 0.346 & & \\
\hline Working Environment & 0.404 & 0.601 & 0.272 & 0.201 & 0.418 & \\
\hline
\end{tabular}

\section{Structural model and hypothesis testing}

The structural model examines the predictive capabilities and causal relationship between the constructs. The bootstrapping technique with resampling (5,000 resamples) was employed to estimate the statistical significance of the hypothesised model.

Table 5 displays the PLS results of the structural model. All five hypothesis are supported by the data. The results show that manager's leadership style has positive significant effect on employee job satisfaction $(\mathrm{H} 1: \beta=0.238, \mathrm{p}<0.01)$, as motivation practices $(\mathrm{H} 2: \beta=0.202, \mathrm{p}<0.01)$, reward management system $(\mathrm{H} 3: \beta=0.130, \mathrm{p}<0.01)$, whereas employee job expectations has a strongest impact on job satisfaction $(\mathrm{H} 4: \beta=0.373, \mathrm{p}<0.01)$ and working environment $(\mathrm{H} 5: \beta=$ $0.216, \mathrm{p}<0.01)$.

Hair Jr et al. (2016) propose that besides portraying the significance of the connections, researchers should also report the coefficient of determination $\left(\mathrm{R}^{2}\right)$, effect size $\left(\mathrm{f}^{2}\right)$ and predictive relevance $\left(\mathrm{Q}^{2}\right)$. Moreover, $\mathrm{R}^{2}$ alludes to the 
explanatory power of the independent variable(s) with respect to their corresponding dependent variables. The model explains 64.2 percent of the variance in employee job satisfaction by the antecedents of work motivation. Following, $\mathrm{f}^{2}$ indicates effect size; how much an independent variable contributes to the dependent variable's $\mathrm{R}^{2} . \mathrm{f}^{2}$ scores above 0.35 , 0.15 , and 0.02 can respectively be stared as strong, moderate, and weak.The results of $\mathrm{f}^{2}$ demonstrate that employee job expectations has a medium to large effect on employee job satisfaction $\left(f^{2}=0.242\right)$, whereas manager's leadership style $(\mathrm{f}=0.115)$, working environment $(\mathrm{f}=0.107)$ have weak to medium effect, while motivation practices $(\mathrm{f}=0.077)$ and reward management system (0.037) weak to small effect. The results of $\mathrm{Q}^{2}$ is revealed that the model has predictive relevance, since $\mathrm{Q}^{2}>0$.

Table 5: the results of structural model assessment

\begin{tabular}{|r|l|r|r|r|}
\hline $\begin{array}{l}\text { Hypo } \\
\text { thesis }\end{array}$ & Paths & $\beta$ & T -Value & Results \\
\hline H1 & $\begin{array}{l}\text { Manager's Leadership Style -> Job } \\
\text { satisfaction }\end{array}$ & 0.238 & 6.246 & Supported \\
\hline H2 & Motivation Practices -> Job satisfaction & 0.202 & 6.170 & Supported \\
\hline H3 & $\begin{array}{l}\text { Reward Management System -> Job } \\
\text { satisfaction }\end{array}$ & 0.130 & 3.191 & Supported \\
\hline H4 & $\begin{array}{l}\text { Employee Job Expectations_-> Job } \\
\text { satisfaction }\end{array}$ & 0.373 & 9.599 & Supported \\
\hline H5 & Working Environment -> Job satisfaction & 0.216 & 8.321 & Supported \\
\hline
\end{tabular}

Table 6: Results of $\mathrm{R}^{2}, \mathrm{Q}^{2}$, and $\mathrm{f}^{2}$

\begin{tabular}{|c|c|c|c|c|}
\hline Latent constructs & $\begin{array}{l}\text { Coefficient of } \\
\text { determination } \\
\left(\mathrm{R}^{2}\right)\end{array}$ & $\begin{array}{l}\text { Predict } \\
\text { relevance } \\
\left(\mathrm{Q}^{2}\right)\end{array}$ & $\mathrm{f}^{2}$ & Effect size \\
\hline Job satisfaction & 64.2 & 0.332 & - & \\
\hline Manager's Leadership Style & - & - & 0.115 & $\begin{array}{l}\text { Small to } \\
\text { medium }\end{array}$ \\
\hline Motivation Practices & - & - & 0.077 & $\begin{array}{r}\text { Weak to } \\
\text { small }\end{array}$ \\
\hline Reward Management System & & - & 0.037 & $\begin{array}{r}\text { Weak to } \\
\text { small } \\
\end{array}$ \\
\hline Employee Job Expectations & - & - & 0.260 & $\begin{array}{r}\text { Medium to } \\
\text { large }\end{array}$ \\
\hline Working Environment & - & - & 0.107 & $\begin{array}{l}\text { Small to } \\
\text { medium }\end{array}$ \\
\hline
\end{tabular}

\section{DISCUSSION AND IMPLICATIONS}

\section{Discussion}

This study examines the relationship between work motivation and employee job satisfaction among 285 employees from technical and supportive employees of CEB, Sri Lanka.

The results of structural analysis is proved that all five work motivation factors influence the employee job satisfaction. The level of influence differs among them. The variables can be categorized in descending order based on level of influence as employee job expectations, manager's leadership style, working environment, motivation practices and reward management system. These findings are in line with several previous research like the study by [40] showed that remuneration, management, work environment, in-service training, tasks and supervision positively affects the job satisfaction.

The results of this study has revealed that the employee job expectations has more positive significant effect on employee job satisfaction at CEB, Batticaloa district. This findings is also supported by [39]. Employee feels that their job is highly secured in terms of security. Similarly, the prevailing job security and the hope that of an employee working at CEB, Batticaloa district can lead a successful life.

The results showed that the manager's leadership style has positive significant effect on job satisfaction of the employee. While employee maintain good relationship with their superiors, they do focus on employee jobs and responsibilities at CEB. Moreover, the managers should direct the subordinates towards developing the skills and working abilities however, this quality of managers need further improvements, as supported by [41]. In addition to this 
it was also observed that the communication with direct supervisor, sharing information and sharing necessary knowledge with employee need to be improved at CEB to further enhance the employee job satisfaction.

Further, the study also indicated that the working environment has a positive effect on their employee satisfaction at CEB, Batticaloa district. Employees highly believe that the working environment is safe and the existence of occupational health care facilities at the work place are up to the requirements. Further the safety of tools and equipment needed to work is also at the satisfactory level [42].

Further, the reward management system at CEB, Batticaloa district is also at the satisfactory level. This shows that a good salary is received by the employees while many employees perceive that the salary level is same to some extent compared to other employees of same category working in other organization. However, a special concern was noted with non-financial rewards such as flexible working hours, long lunch time, extra vacation days, health care plan and insurance plan motivate them. However, it is noted that non-financial rewards are available at CEB, however employees are not much inspired by them [43].

\section{CONCLUSION AND LIMITATIONS}

\section{Conclusion}

Motivation is the most crucial part in HRM and many organizations use various distinct strategies to retain their human resources. Literature evidenced that high level of motivation pushes greater level of job satisfaction. In that ground, factors affecting employee job satisfaction can be dependent on five factors namely manager's leadership style, motivation practices, reward management system, employee job expectations and working environment. As researcher, believed that these five categories do not provide equal weight for employee job satisfaction; this research focused on finding the corresponding weights or gravity given by these five classifications on employee job satisfaction. The researcher was interested to identify to what extent have the five factors impacted on employee job satisfaction based on the study of Ceylon Electricity Board in Batticaloa district. The overall objective was to assess the influence of employee motivation on job satisfaction in Ceylon Electricity Board in Batticaloa district. It was found out that all the five work motivation factors influence the employee job satisfaction. Among them the highest influence is made by employee job expectation at CEB, Batticaloa district whereas the lowest influence is made by reward management system of CEB, Batticaloa district.

\section{Limitations}

The present study analyzed the impact of work motivation on employee job satisfaction in Ceylon Electricity Board, Batticaloa district. It may be extended to various other service industries which rely on employees' work motivation extensively. This study can be extended by including the other variables such as co-worker support, workload, stress level, fair policies and practice, creativity at job and personal interests which determine the employee job satisfaction that can facilitate to enhance the findings of this study. Further examinations should be possible in different areas in Sri Lanka in a similar setting and this can additionally approve the findings of this research.

Appendix 01: Cross loading

\begin{tabular}{|c|c|c|c|c|c|c|}
\hline & $\begin{array}{l}\text { Employee Job } \\
\text { Expectations }\end{array}$ & $\begin{array}{l}\text { Job } \\
\text { satisfaction }\end{array}$ & $\begin{array}{l}\text { Manager's } \\
\text { Leadership } \\
\text { Style }\end{array}$ & $\begin{array}{l}\text { Motivation } \\
\text { Practices }\end{array}$ & $\begin{array}{l}\text { Reward } \\
\text { Management } \\
\text { System }\end{array}$ & $\begin{array}{l}\text { Working } \\
\text { Environment }\end{array}$ \\
\hline JE1 & 0.827 & 0.59 & 0.23 & 0.299 & 0.221 & 0.156 \\
\hline JE2 & 0.75 & 0.531 & 0.385 & 0.306 & 0.256 & 0.399 \\
\hline JE3 & 0.84 & 0.603 & 0.528 & 0.462 & 0.089 & 0.264 \\
\hline JE4 & 0.775 & 0.473 & 0.21 & 0.204 & 0.426 & 0.245 \\
\hline JE5 & 0.816 & 0.493 & 0.305 & 0.46 & 0.313 & 0.325 \\
\hline JS2 & 0.558 & 0.727 & 0.393 & 0.394 & 0.128 & 0.425 \\
\hline JS3 & 0.582 & 0.869 & 0.482 & 0.335 & 0.438 & 0.479 \\
\hline JS4 & 0.486 & 0.783 & 0.391 & 0.371 & 0.319 & 0.281 \\
\hline JS8 & 0.347 & 0.554 & 0.422 & 0.476 & 0.157 & 0.261 \\
\hline L1 & 0.335 & 0.564 & 0.91 & 0.457 & 0.135 & 0.307 \\
\hline $\mathrm{L} 2$ & 0.472 & 0.519 & 0.917 & 0.25 & 0.357 & 0.147 \\
\hline
\end{tabular}




\begin{tabular}{|l|r|r|r|r|r|r|} 
L5 & 0.347 & 0.493 & 0.803 & 0.435 & 0.272 & 0.247 \\
\hline L7 & 0.207 & 0.237 & 0.725 & 0.213 & 0.092 & 0.11 \\
\hline M1 & 0.519 & 0.561 & 0.386 & 0.907 & 0.038 & 0.204 \\
\hline M3 & 0.102 & 0.243 & 0.318 & 0.677 & -0.177 & 0.11 \\
\hline M4 & 0.414 & 0.491 & 0.451 & 0.918 & 0.001 & 0.399 \\
\hline M7 & 0.327 & 0.409 & 0.278 & 0.922 & -0.105 & 0.23 \\
\hline R1 & 0.206 & 0.337 & 0.212 & -0.084 & 0.825 & 0.274 \\
\hline R2 & 0.284 & 0.283 & 0.258 & 0.023 & 0.84 & 0.367 \\
\hline R4 & 0.26 & 0.203 & 0.144 & -0.029 & 0.649 & -0.066 \\
\hline WE1 & 0.309 & 0.503 & 0.28 & 0.13 & 0.222 & 0.747 \\
\hline WE2 & 0.251 & 0.366 & 0.126 & 0.369 & 0.207 & 0.722 \\
\hline WE3 & 0.268 & 0.359 & 0.255 & 0.24 & 0.241 & 0.921 \\
\hline WE4 & 0.182 & 0.196 & 0.024 & 0.165 & 0.201 & 0.71 \\
\hline
\end{tabular}

\section{References}

[1]. Ling Wenquan, Fang Liluo, and Chen Jiazhou, "Reviews of Researches on the Psychological Contract in Organizations", Journal of Management Sciences in China, Journal Press of Management Sciences in China, Tianjin, 2001, 2, pp. 74-78.

[2]. Ran Bin, Measurement Manual of Job Satisfaction, Sea Sky Publisher House, Shenzhen, 2002.

[3]. Darren George, Paul Mallery, SPSS for Windows Step by Step, Beijing World Publishing Corporation, Beijing, 2006.

[4]. Li Yuan, Psychological Contract of Enterprise Employee, Fudan Press, Shanghai, 2006.

[5]. M. D. Hartline and O.C. Ferrell, "The Management of Customer Contact Service Employees: An Empirical Invcstiuation[J]", Journal of Marketing, vol. 60, no. 4, pp. 52-70, 1996.

[6]. D. Natalisa and B. Subroto, "Effects of Management Commitment on Service Quality to Increase Customer Satisfaction of Domestic Airlines in Indonesia[J]", Singapore Management Review, vol. 25, no. 1, pp. 85-104, 2003.

[7]. J. L. Heskett, T. O. Jones, G. W. Loveman, W. E. Sasser and L. A. Schlesinger, "Putting the Service-Profit Chain to Work[J]", Harvard Business Review, vol. 72, no. 2, pp. 164-174, 1994.

[8]. K. D. Hoffman and T.N. Ingram, "Service Provider Job Satisfaction and Customer-Oriented Performance[J]", Journal of Services Marketing, vol. 6, no. 2, pp. 68-78, 1992.

[9]. D. W. Organ, Organizational Citizenship Behavior: The Good Soldier Syndrome[M], Lexington, MA:Lexington Books, 1988.

[10]. S. J. Bell and B. Menguc, "The Employee-organization Relationship Organizational Citizenship Behaviors and Superior Service Quality[J]", Journal of Retailing, vol. 78, no. 2, pp. 131-146, 2002.

[11]. W.H. Mobley, "Intermediate Linkage in the Relationship Between Job Satisfaction and Employee Turnover[J]", Journal of Applied Psychology, vol. 62, no. 2, pp. 237-240, 1977.

[12]. Hu Yuexiao, "The Relationship between Satisfied Feeling and Work Performance[J]", Contemporary Economy \& Management, vol. 28, no. 26, pp. 57-60, 2006.

[13]. Hui Tiaoyan and Yang Naiding, "Research on the Relationship between Job Satisfaction and Performance[J]", Soft Science, no. 4, pp. $62-$ $65,2006$.

[14]. Wu Xiaoyi, Wang Chunxiao, Xie Lishan and Zhang Xiujuan, "Effects of Employees' Perception of Pay Fairness in Restaurant[M]", Guangzhou: Press of Sun Yat-sen University, pp. 1-76, 2006.

[15]. Herbert G. Heneman and Donald P. Schwab, "Pay Satisfaction: Its Multidimensional Nature and Measurement[J]", International Journal of Psychology, vol. 20, no. 2, pp. 129-141, 1985.

[16]. Borman W C and Motowidlo S J, "Task and Contextual Performance: The Meaning for Personnel Selection research[J]", Human Performance, vol. 10, no. 2, pp. 99-109, 1997.

[17]. A Bryson, L Cappellari and C Lucifora, "Why So Unhappy? The Effects of Unionization on Job Satisfaction", Oxford Bulletin of Economics and Statistics, vol. 72, no. 3, pp. 357-380, 2010.

[18]. P A Bamberger and A N Kluger, "Suchard R. Research Notes: The Antecedents and Consequences of Union Commitment: A MetaAnalysis", Academy of Management Journal, vol. 42, no. 3, pp. 304-318, 1999.

[19]. J Barling and B Wade, "Fullagar C. Predicting employee commitment to company and union: Divergent models", Journal of Occupational Psychology, vol. 63, no. 1, pp. 49-61, 1990.

[20]. R.W. Brislin, "Translation and content analysis of oral and written material", Handbook of Cross-Cultural Psychology, vol. 2, no. 2, pp. 349-444, 1980.

[21]. A W Chan and E. Snape, "Are cultural values associated with organizational and union commitment and citizenship behavior? A study of Chinese manufacturing workers", Asia Pacific Journal of Management, vol. 30, no. 1, pp. 169-190, 2013.

[22]. H. E. Baker, "Linking organizational socialization tactics with corporate human resource management strategies", Human Resource Management Review, 1991, Vol. 1, pp193-202.

[23]. B. Barbara, A. Petroni, and Al. Dormio, "Organizational socialization, career aspirations and turnover intentions among design engineers", Leadership \& Organization Development Journal, 2005, Vol. 26, pp424-441. (Pubitemid 41403443) 
[24]. J. S. Black and H. B. Gregersen, "Participative Decision-Making: AN Integration of Multiple Dimensions", Human Relations, 1997, Vol. 50, pp859-878.

[25]. W. C. Borman and S. J. Motowidlo, "Expanding the criterion domain to include elements of contextual performance", In Schmitt N, Borman W, C, \& Associates (Eds.), Personnel Selection in Organizations, Jossey-Bass, San Francisco, 1993.

[26]. R. W. Brislin, "Translation and content analysis of oral and written materials", In H. C. Triandis \& J.W. Berry (Eds.), Handbook of crosscultural psychology, vol. 2, pp389-444, 1980. Boston, MA: Allyn and Bacon.

[27]. G. T. Chao, A. M. Leary-Kelly, S. Wolf, H. J. Kein, and P. D. Gardner, "Organizational socialization: its content and consequences", Journal of Applied Psychology, Vol. 79, pp 730-743, 1994.

[28]. Z. X. Chen and A. M. Francesco, "The Relationship between the Three Components of Commitment and Employee Performance in China", Journal of Vocational Behavior, Vol. 62, pp 490-510, 2003. (Pubitemid 36668186)

[29]. D. B. Greenberger, S. Strasser, L. L. Cummings, and R B. Dunham, "The impact of personal control on performance and satisfaction Original Research", Article Organizational Behavior and Human Decision Processes, Vol. 43, pp29-51, 1989.

[30]. G. R. Jones, "Socialization tactic, self-efficacy, and newcomers' adjustments to organizations", Academy of Management Journal, Vol. 29, pp262-279, 1986.

[31]. M. V. Kramer, "A longitudinal study of superior-subordinate communication during job transfers", Human Communication Research, Vol. 22, pp39-64, 1995.

[32]. Li Zhipeng, "The study on the relationship between organizational support, organizational commitment and job satisfaction", Unpublished.

[33]. J. P. Meyer and N. J. Allen, "Commitment to Organizations and Occupations: Extension and Teset of a Three Component Conceptualization", Journal of Applied Psychology, Vol. 78, pp538-551, 1993.

[34]. J. P. Meyer and N. J. Allen, "Commitment in the workplace: Theory, research, and application", Thousand Oaks, CA: Sage Publications, 1997.

[35]. S. J. Motowidlo and J. R. Van Scotter, "Evidence that task performance should be distinguished from contextual performance", Journal of Applied Psychology, Vol. 79, pp475-480, 1994.

[36]. Qian Ying, "The Study on the Structure of Employees' Organizational Socialization and relationship between the Structure and Behavior Performance", Unpublished.

[37]. T. N. Bauer and S. G. Green, "Testing the Combined Effects of Newcomer Information Seeking and Manager Behavior on Socialization", Journal of Applied Psychology, Vol. 83, pp72-83, 1998.

[38]. R. J. Taormina, "Organizational socialization: a multidomain, continuous process model", International Journal of Selection and Assessment, Vol. 5, pp29-47, 1997.

[39]. R. J. Taormina, "Employee attitudes toward organizational socialization in the People's Republic of China, Hong Kong, and Singapore", Journal of Applied Behavioral Science, Vol. 34, pp468-485, 1998. (Pubitemid 128167734)

[40]. Wang Yanfei, "Research on employee achievement goal orientation", Unpublished dissertation thesis of Chinese Academy of Sciences, 2002.

[41]. Wang Yanfei and Zhang Rentian, "An Empirical Study on Interaction among Organizational Sociation and Employees Performance according to Psychological Ownership", Unpublished.

[42]. D. J. Weiss, R.V. Dawis, G. W. England, and L. H. Lofquist, "Manual for the Minnesota Satisfaction Questionnaire", Industrial Relations Center, University of Minnesota, Minneapolis, 1967.

[43]. Zhao Guoxiang, Wang Minghui, and Ling Wenquan, "Construct dimension of the employee's content of organizational socialization in China", Acta Psychologica Sinica, Vol. 39, pp1102-1110, 2007. 